\title{
Seasonal Variability of the Diurnal Cycle of the Black Sea Surface Temperature from the SEVIRI Satellite Measurements
}

\author{
V. A. Rubakina*, A. A. Kubryakov, S. V. Stanichny \\ Marine Hydrophysical Institute of RAS, Sevastopol, Russian Federation \\ *valenru93@mail.ru
}

\begin{abstract}
Introduction. Heat and gas exchange between the ocean and the atmosphere, and stratification and vertical mixing in the sea upper layer are subjected to the diurnal variations of the sea surface temperature.

Data and methods. The data obtained by the scanner SEVIRI in 2015 (time resolution is 1 hour) are used to study seasonal and spatial variability of the sea surface temperature diurnal cycle in the Black Sea.

Results. During a day, the upper layer heats from 6:00 to 17:00 (the highest temperature) and then cools from 19:00 to 5:00 (the next morning) up to its minimum. The largest diurnal deviations of the sea surface temperature from the average seasonal ones are observed in spring-summer $\left( \pm 0.8^{\circ} \mathrm{C}\right)$, whereas the lowest deviations are typical of the autumn-winter period $\left( \pm 0.1-0.2{ }^{\circ} \mathrm{C}\right)$. A few cases when the diurnal warming is high were detected and analyzed. In some regions, the amplitude of the sea surface temperature diurnal cycle exceeded $5{ }^{\circ} \mathrm{C}$ and reached its extreme values $7-7.2{ }^{\circ} \mathrm{C}$. The low wind speed (less than $4 \mathrm{~m} / \mathrm{s}$ ) is an important reason of these extreme events. The most often intensive diurnal warming is due to the low wind conditions which are highly frequently observed in May. In winter the values of the sea surface temperature diurnal amplitude are minimum and do not exceed $1.5^{\circ} \mathrm{C}$. Since April, they sharply increase and reach their maximum $2.4{ }^{\circ} \mathrm{C}$ in May. The most significant sea surface temperature diurnal amplitude is observed in the Black Sea southeast region and in its southwest coastal part. Such spatial distribution is a result of the wind shadow zone which is formed by the Caucasian and Pontic mountains.

Discussion and conclusion. The features of spatial and seasonal variability of the Black Sea surface temperature diurnal cycle, and its relation to the wind characteristics in different seasons are studied based on the SEVIRI scanner high-frequency measurements.
\end{abstract}

Keywords: sea surface temperature, SEVIRI, amplitude of diurnal variation, diurnal warming.

Acknowledgments: the features of seasonal variability of the SST diurnal variation are determined at support of the RFBR grant No.17-05-41102 RGO_a. Relation between the SST diurnal variation and the wind characteristics is studied at support of the RFBR grant No. 16-35-60036 mol_a_dk. The data are analyzed and processed within the state task on the theme No. 0827-2018-0002.

For citation: Rubakina, V.A., Kubryakov, A.A. and Stanichny, S.V., 2019. Seasonal Variability of the Diurnal Cycle of the Black Sea Surface Temperature from the SEVIRI Satellite Measurements. Physical Oceanography, [e-journal] 26(2), pp. 157-169. doi:10.22449/1573-160X-2019-2-157-169

DOI: $10.22449 / 1573-160 X-2019-2-157-169$

(C) 2019, V. A. Rubakina, A. A. Kubryakov, S. V. Stanichny

(C) 2019, Physical Oceanography

\section{Introduction}

The most important feature of the World Ocean state, and the Black Sea in particular, is the ocean/sea surface temperature (SST), affecting the climate and the functioning of the earth ecosystem. The SST increase can lead to more frequent occurrence of tropical cyclones, hurricanes and typhoons, their strengthening and, as a result, an increase in the damage caused by them [1]. The SST diurnal cycle 
causes breeze winds, which can significantly affect the exchange processes in the Black Sea coastal zone [2,3]. This parameter is directly used in the calculations of turbulent heat exchange between the ocean and the atmosphere [4]. SST significantly affects the accuracy of ocean and atmosphere parameters estimation (wind speed, salinity, water vapor content, etc.) from satellite measurements in the microwave range [5-7]. All this necessitates monitoring of SST, its diurnal and seasonal variations.

The SST diurnal cycle is determined by the combined action of the following three factors: solar radiation, turbulent mixing and heat transfer dynamics between the ocean and the atmosphere. During the day, in conditions of clear sky and weak wind, the near-surface water temperature rises due to the absorption of incoming short-wave solar radiation. It results in the formation of significant vertical temperature gradient. At night, convective mixing destroys the diurnal thermocline [8].

Since the solar heat absorption is most intense on the surface, the maximum temperature increase is observed within the thin surface layer boundaries (at a depth of 0.5-1 m). However, wind mixing can propagate the absorbed heat down into the water column. Thus, the warming layer can expand to a depth of 10-20 m [8].

The magnitude of the SST diurnal cycle amplitude depends on cloud cover, determining the amount of incident solar radiation, and on wind mixing. Under insignificant cloudiness and weak wind SST can rise during daytime on up to $5{ }^{\circ} \mathrm{C}$ at a depth from $0.3-0.6$ [8] to $7 \mathrm{~m}$ [9]. In summer, due to intense solar radiation and low winds, daily variations in surface temperature are greater than in the winter months *.

With the appearance of satellite measurements on the geostationary orbit, it became possible to obtain information of the ocean and atmosphere parameters on a planetary scale with a very high temporal discreteness - from 5 minutes. These data made it possible to analyze the processes of variability of cloudiness, temperature and other parameters on time scales from several minutes to days for the first time.

Currently, one of the best instruments for SST determination with a high temporal discreteness is the SEVIRI (Spinning Enhanced Visible and Infrared Imager) scanner installed on MSG (Meteosat Second Generation) geostationary meteorological satellites [4]. SEVIRI has a relatively high spatial resolution (from 4 to $6 \mathrm{~km}$ ). Such parameters make it possible to use its data for studying the cyclic process of diurnal warming effectively [9-12]. For example, according to the data of this scanner, in [13], an analysis of the SST diurnal cycle features for the Atlantic Ocean and several European seas was carried out. Using the data of SEVIRI, drifters and numerical modeling, a detailed study of SST (diurnal cycle and warming and cases of extreme diurnal warming) for the Mediterranean Sea for 2013 was carried out in [4]. The thermal balance of the Mediterranean Sea was assessed and the seasonal and diurnal variations in heat balance were analyzed.

* Davydov, L.K., Dmitrieva, A.A. and Konkina, N.G., 1973. Obchshaya Gidrologiya [General Hydrology]. Leningrad: Gidrometeoizdat. Available at: http://elib.rshu.ru/files_books/pdf/img216094822.pdf [Accessed: 15 November 2018] (in Russian). 
It was noted that diurnal warming with an amplitude of more than $1{ }^{\circ} \mathrm{C}$ is characteristic for the entire Mediterranean Sea basin. Extreme diurnal warming events were most often recorded in the summer, with the maximum number occurring in July. The maximum amplitude of the diurnal variation in such cases exceeded $5{ }^{\circ} \mathrm{C}$. The correlation of wind intensity and the magnitude of the SST diurnal variation amplitude was also revealed. It was noted that diurnal warming events were observed in winter, spring and autumn, but with a lower periodicity.

However, the potential possibility of the SEVIRI scanner application for analyzing the SST diurnal variation in the Black Sea was used only in [14]. In this study the method for reducing the average error in the determination of SST fields based on the SEVIRI satellite sensor data for the Black Sea area was developed. The SST diurnal variation has a pronounced seasonal variability, which is associated with the seasonal variation of heat flows and wind speed. The present paper is aimed to study the SST diurnal cycle dynamics of the Black Sea in different seasons and to analyze its spatial features according to the SEVIRI scanner data.

\section{The data used}

The SEVIRI scanner data for 2015 on SST with 1 hour resolution and spatial resolution of $5 \mathrm{~km}$ was used in the study. The temperature measured in the IR range is formed in a thin layer $(\sim 0.1 \mathrm{~mm})$ and represent the temperature of the skin layer [14, 15]. Data was obtained from the OSI SAF EUMETSAT archive (http://www.osi-saf.org/). Based on a comparison of the SEVIRI sensor data and in situ measurements by free-drifting buoys (drifters), in [14] the estimates of the measurement accuracy were given. The rms deviation of the difference between these measurements was about $0.45 \mathrm{~K}$.

For the wind field analysis, the Era-Interim reanalysis data on wind speed at a height of $10 \mathrm{~m}$ with a resolution of 6 hours and a spatial resolution of $0.75^{\circ}$ [16], obtained from the ECMWF archive (https://www.ecmwf.int/), were used. In [17] it the Era-Interim data were shown to be in a reasonable agreement with in-situ measurements.

\section{Results and their analysis}

\section{The average SST diurnal cycle in the Black Sea and its seasonal dynamics}

To analyze the seasonal dynamics of the average SST diurnal cycle, the distribution of the average over the basin SST was calculated depending on the time of day and month. For this, average over the basin SST for each point in time was first calculated. Then, the average value for a particular hour of the day of each month was counted. The resulting diagram is presented in Fig. 1, $a$.

\footnotetext{
* Available at: http://d33.infospace.ru/d33_conf/tarusa2018/05.pdf [Accessed: 20 January 2019].
} 


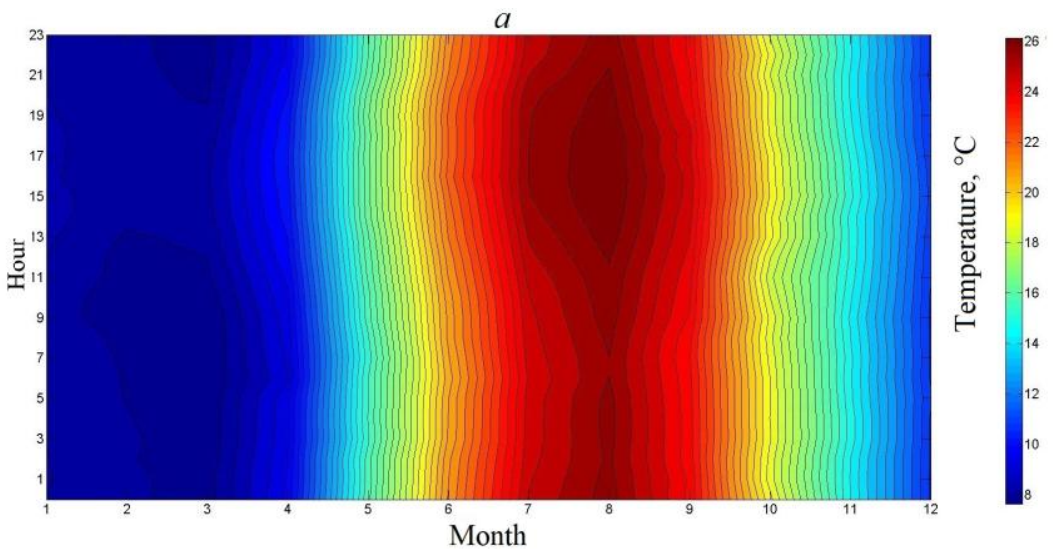

$b$

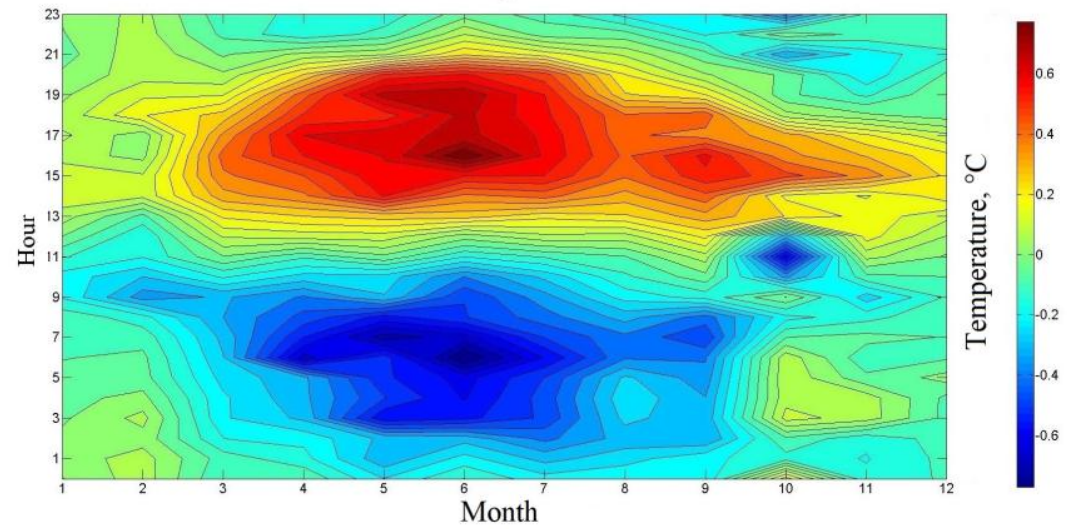

F i g. 1. Diagram of distribution of: $a$-average over the basin SST; $b$-SST deviations from the average seasonal ones on month and local time based on the SEVIRI data

As can be seen from Fig. 1, $a$, the dominant contribution to the SST variability is the seasonal cycle. The maximum temperature is observed in July - August 2015 when it reaches $28^{\circ} \mathrm{C}$. At that, the highest values are recorded in August in the second half of the day (15:00-19:00 local time) and the lowest ones - in February - March in the first half of the day (from 3:00 to 5:00).

In order to-estimate the diurnal temperature variation, the values of the SST average seasonal variation were subtracted from the data set in diagram in Fig. 1, $a$. The diagram of SST anomalies obtained in this way (Fig. 1, b) clearly shows that the diurnal variation has a significant effect on the SST variability and has a pronounced seasonal dynamics.

The maximum negative anomalies of SST fall on time from 5:00 to 7:00, and the maximum positive ones - from 15:00 to 19:00. Thus, the warming of the upper layer is observed from 6:00 to 17:00 on average, and cooling - from 19:00 to 5:00 the next morning. The greatest SST deviations from the average seasonal values are observed in the spring-summer period (from April to July), with the largest anomalies occurring in June. The maximum (in absolute value) values of the anomalies are $0.82{ }^{\circ} \mathrm{C}$ in the direction of increasing temperature and $0.77{ }^{\circ} \mathrm{C}$ in 
the direction of decreasing. Minimal anomalies are observed from mid-November to March and do not exceed (in absolute value) $0.1-0.2^{\circ} \mathrm{C}$.

Fig. 2 shows the spatial distribution of the June average SST, measured at 7:00 (Fig. 2, $a$ ) and 17:00 (Fig. 2, b) of the local time, as well as a chart of the temperature difference (Fig. 2,c). These maps clearly demonstrate the spatial variability of the diurnal temperature variations. At 7:00 the SST is lower, and at 5:00 pm - higher than the monthly average. The difference between the temperature values at 17:00 and 7:00 reaches $3.5-4{ }^{\circ} \mathrm{C}$ in some areas of the Black Sea, e.g. in the southeast of the basin.

The largest warming areas are located in the Azov Sea and in the southeastern Black Sea basin. The shallow depth of the Azov Sea contributes to its rapid warming. In the southeast of the Black Sea, wind speed is minimal, due to the blocking of air masses by the high Caucasus Mountains. In general, for June diurnal warming with amplitude $1{ }^{\circ} \mathrm{C}$ or higher is typical for almost the entire water area of the Black Sea basin. The minimum temperature difference (less than $0.2{ }^{\circ} \mathrm{C}$ ) is noted only for small-sized areas, mainly in the coastal zone, particularly in the area of the Southern Coast of Crimea. This may be due to local features of the coastal zone dynamics, for example, breeze and/or upwelling effects.

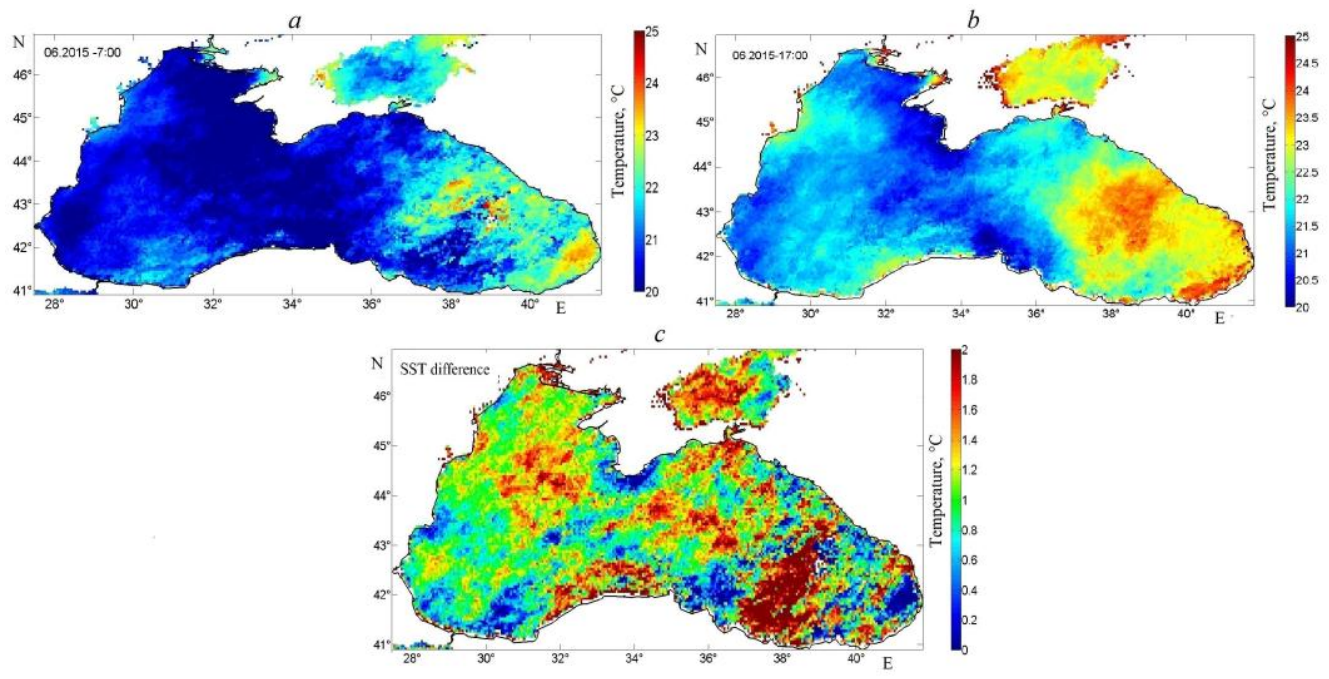

F i g. 2. Spatial distribution (June, 2015) of the average SST at 7:00 (a), at 17:00 (b); difference of the average values of SST in June at 17:00 and 7:00, local time (c)

\section{The SST diurnal cycle amplitude in the Black Sea}

The estimates above relate to the average SST diurnal cycle, which is primarily determined by the diurnal variations of short-wave solar radiation. Another important factor that significantly affects the high-frequency SST variations is wind. During periods of calm under the action of solar radiation, the thickness of the upper mixed layer (ML) is significantly reduced, which leads to 
the SST increase [9]. Wind mixing increase mixed layer depth and to heat it up, a greater amount of heat is required.

A strong diurnal warming event associated with calm wind conditions was observed on May 11, 2015. Fig. 3, $a$ and 3, $b$ shows the spatial SST distribution at 3:00 and 16:00 (local time) on May 11, 2015. At 3:00 the SST in most of the sea does not exceed $13{ }^{\circ} \mathrm{C}$. In some areas of the western and southwestern parts of the Black Sea, as well as in the eastern part of the Azov basin, the SST was higher from 14.5 to $15.9^{\circ} \mathrm{C}$. On the map at 16:00, SST is much higher. It exceeds $16^{\circ} \mathrm{C}$ throughout the basin, except the coastal areas of the Crimea and the southwestern Black Sea. In these areas, SST also increases, but its values are somewhat lower (13.6-14.5 $\left.{ }^{\circ} \mathrm{C}\right)$.

To calculate the amplitude of the diurnal cycle $(A)$ according to the SEVIRI data, at each point where satellite measurements of SST were available, its maximum and minimum values per day and their difference - the amplitude of the diurnal temperature variation was determined. On May $11,2015 A$ is over $2{ }^{\circ} \mathrm{C}$ in most of the basin, and in certain areas it exceeds $5{ }^{\circ} \mathrm{C}$ (Fig. 3, c).
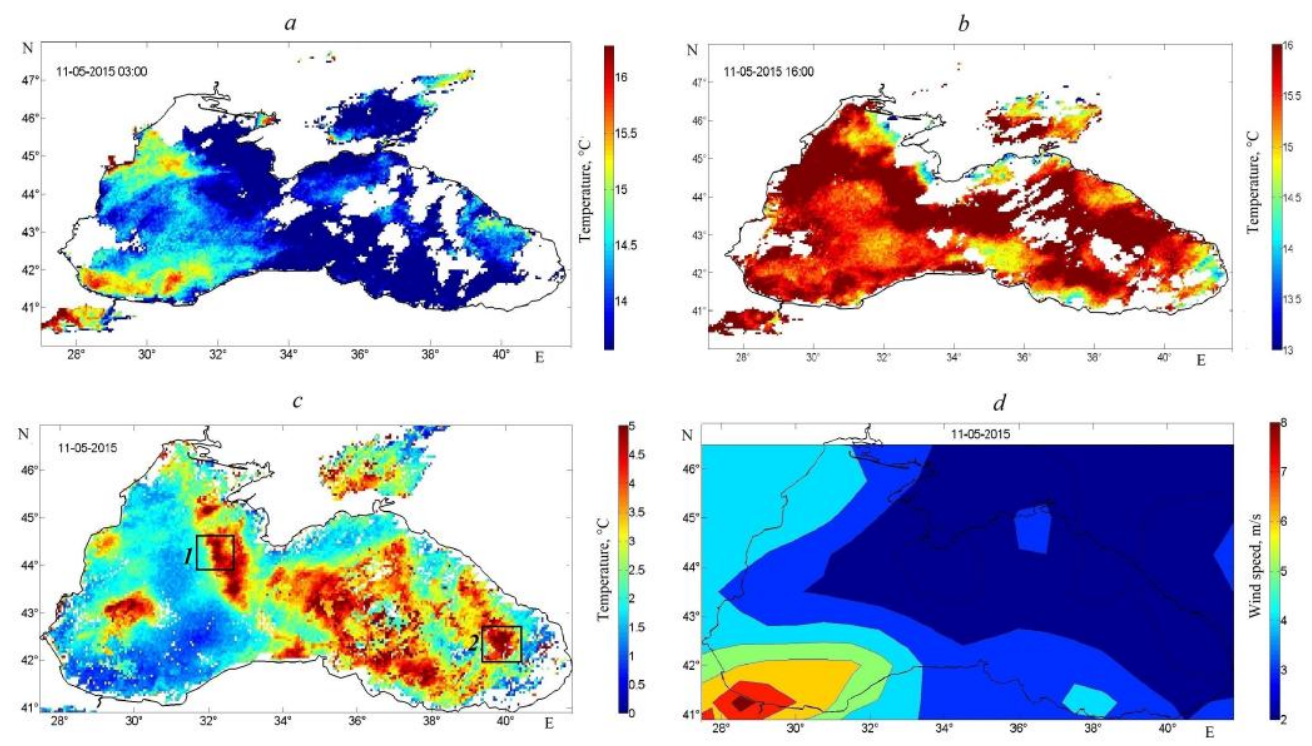

F i g. 3. Spatial distribution (11.05.2015) of: $a-\operatorname{SST}\left({ }^{\circ} \mathrm{C}\right)$ at $3.00 \mathrm{~h} . ; b-\operatorname{SST}\left({ }^{\circ} \mathrm{C}\right)$ at $16.00 \mathrm{~h} ; c-$ amplitude of the SST diurnal cycle $\left({ }^{\circ} \mathrm{C}\right) ; d$ - mean value of the wind speed module $(\mathrm{m} / \mathrm{s})$. The rectangles denote the areas within which the points intended for analysis are chosen

Fig. 4 shows that on May 11, 2015, the average SST in the basin from 00:00 to 6:00 almost does not change, from 6:00 to 9:00 begins to increase gradually. From 9:00 to 14:00, the sharpest warming takes place, when the SST rises from 14.3 to $15.8^{\circ} \mathrm{C}$. From $14: 00$ to $16: 00 \mathrm{SST}$ was constane, then it decreases to $14.7^{\circ} \mathrm{C}$. 

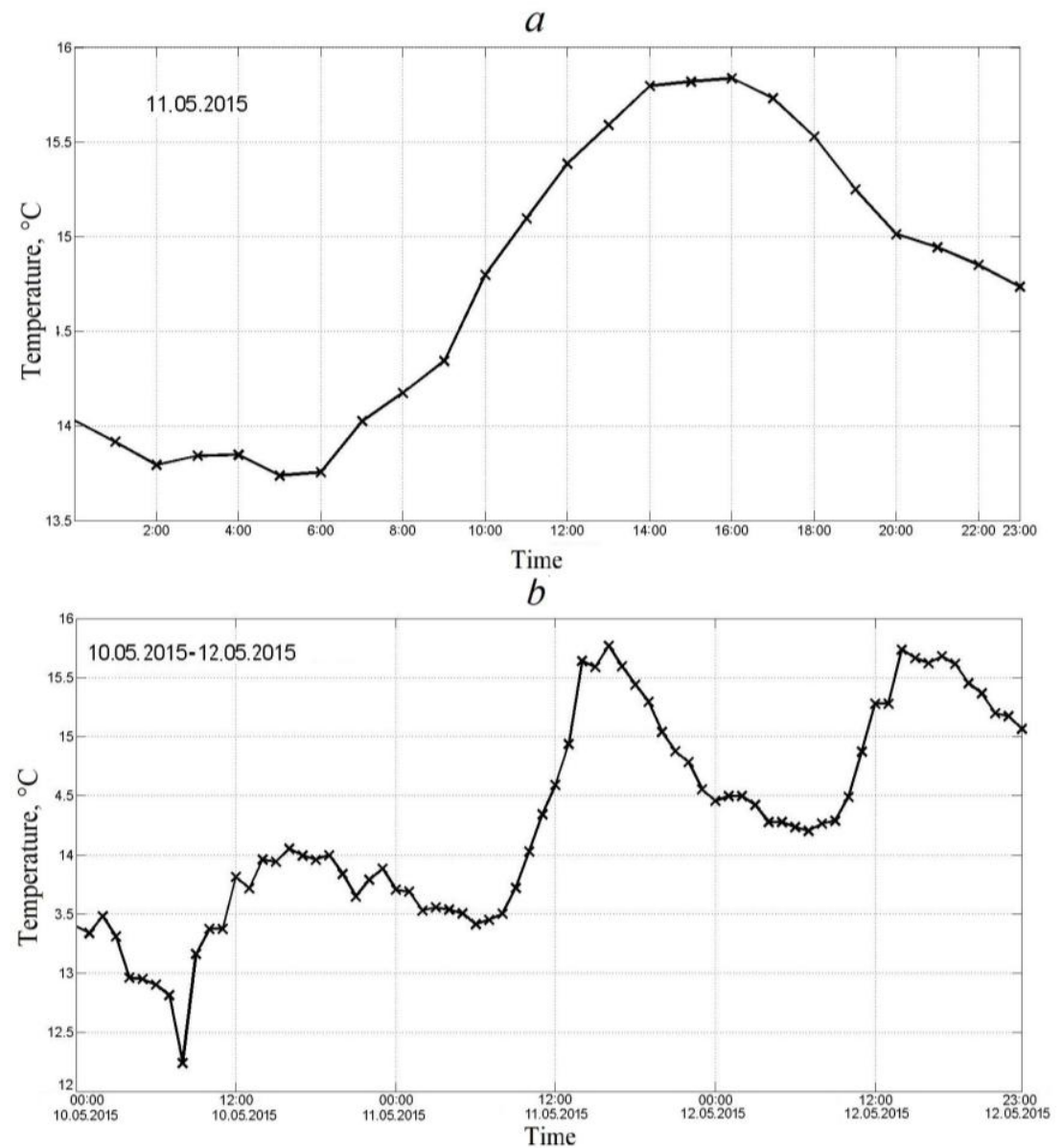

$c$

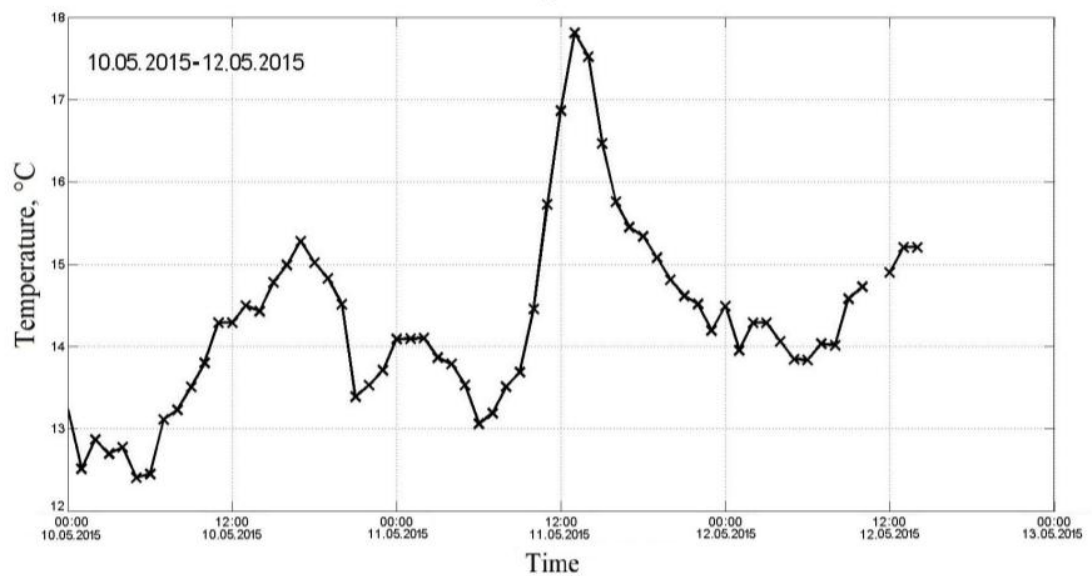

F i g. 4. Variability of: $a$ - SST average over the Black Sea area, 11.05.2015; $b$-average SST for the region 1 from 10.05.2015 to 12.05 .2015 (see Fig. 3,c); $c$ - average SST for the region 2 from 10.05.2015 to 12.05 .2015 
In Fig. 4, $b$ and 4, $c$, the SST variations are shown in areas characterized by the highest values of temperature difference (black rectangles in Fig. 3, c). It is seen that on May 11, 2015, the most significant SST variation occurs during the day. On this day, there is an intensive SST growth in the first half of the day and a rather sharp decrease in the second half compared with May 10, 2015. In area 1, the minimum SST value is $13.4^{\circ} \mathrm{C}$, the maximum one $-15.8^{\circ} \mathrm{C}$. The amplitude of the SST diurnal cycle was $2.4^{\circ} \mathrm{C}$.

Diurnal warming in area 2 is even more pronounced (Fig. 4, c). A sharp increase in SST from a minimum $\left(13^{\circ} \mathrm{C}\right)$ to a maximum $\left(17.8^{\circ} \mathrm{C}\right)$ is observed from 6:00 to $13: 00$, and then there is a decrease to $14.2{ }^{\circ} \mathrm{C}$ (at 23:00). Thus, the amplitude of the SST diurnal variation at this point reaches $4.8^{\circ} \mathrm{C}$.

Note that in some points of the basin on May 11, 2015, the SST diurnal variation amplitude reaches extremely high values and is $7-7.2^{\circ} \mathrm{C}$. The same high values were recorded in the Atlantic Ocean area in previous works, particularly, in [9]. Such strong diurnal heating can significantly change the heat fluxes between the ocean and the atmosphere. This in turn can significantly affect the quality of reproduction of the atmospheric circulation in numerical models. In addition, the SST increase can cause a decrease in the oxygen flow into the water column, which negatively affects the functioning of the marine ecosystem.

The reason for such sharp SST rise was the low wind conditions observed over the Black Sea from May 10 to 12, 2015. As can be seen from Fig. 5, the average wind speed over the Black Sea during this period did not exceed $4 \mathrm{~m} / \mathrm{s}$. The lowest wind speeds $(<3.4 \mathrm{~m} / \mathrm{s})$ are recorded from 00:00 on May 10 to 12:00 on May 11 local time. In this case, the minimum wind speeds $(\sim 2.5 \mathrm{~m} / \mathrm{s})$ are observed immediately before the start of the most intensive SST growth on May 11 at 3:00 local time.

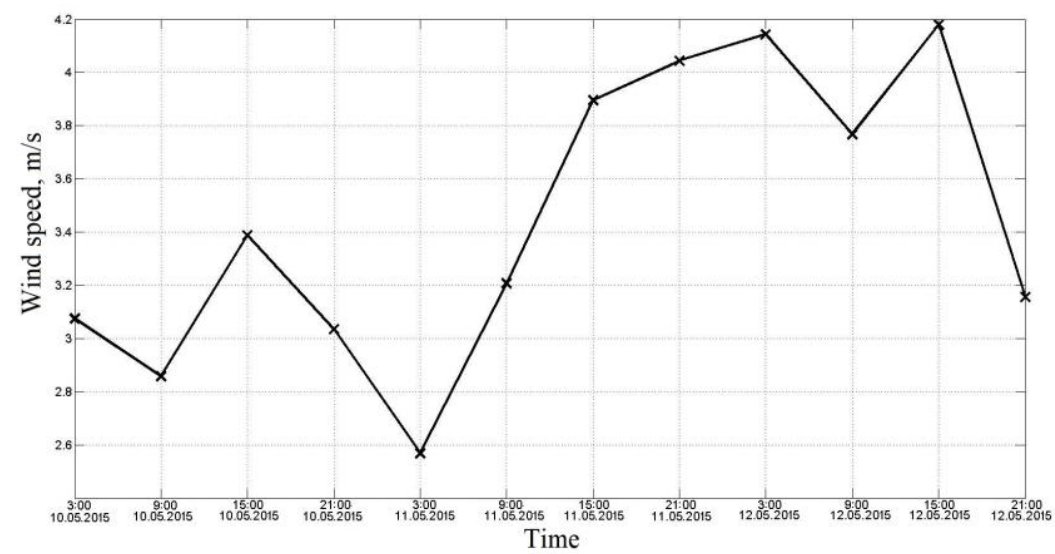

F i g. 5. Wind speed variation averaged over the Black Sea from 10.05.2015 to 12.05.2015

Fig. 3, $d$ is a map of the average value of the wind speed on May 11, 2015. Over most of the Black Sea, the wind speed is very low and does not exceed $3 \mathrm{~m} / \mathrm{s}$. The exception is the southwestern area, where it reaches $6-8 \mathrm{~m} / \mathrm{s}$. There the amplitude of the diurnal variation is low (Fig. 3, c) and does not exceed $1.5{ }^{\circ} \mathrm{C}$. 
Over the eastern part of the sea, wind speed is the lowest $(<2 \mathrm{~m} / \mathrm{s})$. This area coincides with the highest values of $A$, which are also observed in the east of the sea. Thus, the main reason for the high diurnal SST variations and their spatial distribution characteristics in this case is the spatial variability of the wind speed.

During 2015 the similar high values of the SST diurnal variations were recorded several times, on: February 26; April 11; May 11, 14, 17, 18 and 25; June 1, 13; July 8, 24, and September 4.

The SST variability for the selected dates showed that on the days of maximum warming, the wind speed did not exceed 3-4 m/s. At the same time, the most frequent maximum SST differences were observed in the southeast basin area. In this part of the Black Sea, wind speeds are on average minimal due to the blocking of air masses by the high Caucasus mountains in the east and the Pontic mountains in the south [18]. Most of the cases of maximum warming are noted in May, since this month is characterized by the lowest wind speeds [19].

Note that not only calm conditions, but also storm winds also lead to sharp variations in surface temperature. Wind turbulent mixing, especially a ML and vertical involvement of deep cold waters. These effects can lead to a decrease in the temperature of the Black Sea by about $10^{\circ} \mathrm{C}$ [20-22]. For example, in [23] it was shown that a powerful quasitropical cyclone in September 2005 caused a decrease in the SST in the central part of the sea from 20 to $8^{\circ} \mathrm{C}$.

Unlike shortwave radiation, wind speed has significant synoptic and highfrequency variability. The phases of the wind speed maximum and minimum occurrence during the day may be different. Therefore, the amplitude values of the SST diurnal variation will differ from the average SST diurnal variations, presented in the previous section of this work.

Fig. 6, $a$ shows the calculated temporal variability of the average over the area of basin $A$ for 2015. The highest values are observed in April - May, when they often exceed $2.5^{\circ} \mathrm{C}$ and reach $3{ }^{\circ} \mathrm{C}$. In these months, the action of largescale centers of atmospheric pressure - the Azores minimum and the Siberian maximum - is minimal on the Black Sea and the wind speed on average does not exceed $5-6 \mathrm{~m} / \mathrm{s}$, which means the diurnal heating effect, will be maximum. A number of high values of $A$ are also observed in June and July, reaching $2.5^{\circ} \mathrm{C}$. The minimum values of $A$ are in January $\left(0.64{ }^{\circ} \mathrm{C}\right)$ and November $\left(0.58{ }^{\circ} \mathrm{C}\right)$.

Seasonal variability of the amplitude of the SST diurnal cycle is presented in Fig. 6b. From January to April, a smooth increase in the amplitude of the diurnal variation is observed. In winter its values are minimal and do not exceed $1.5^{\circ} \mathrm{C}$. Further, there is a sharp increase in $A$ to a maximum value of $2.4{ }^{\circ} \mathrm{C}$ in May, after which it gradually decreases. In summer $A$ takes the values of $1.7-2{ }^{\circ} \mathrm{C}$. In autumn, its further decrease from $1.85^{\circ} \mathrm{C}$ in September to $1.45^{\circ} \mathrm{C}$ in November takes place. 

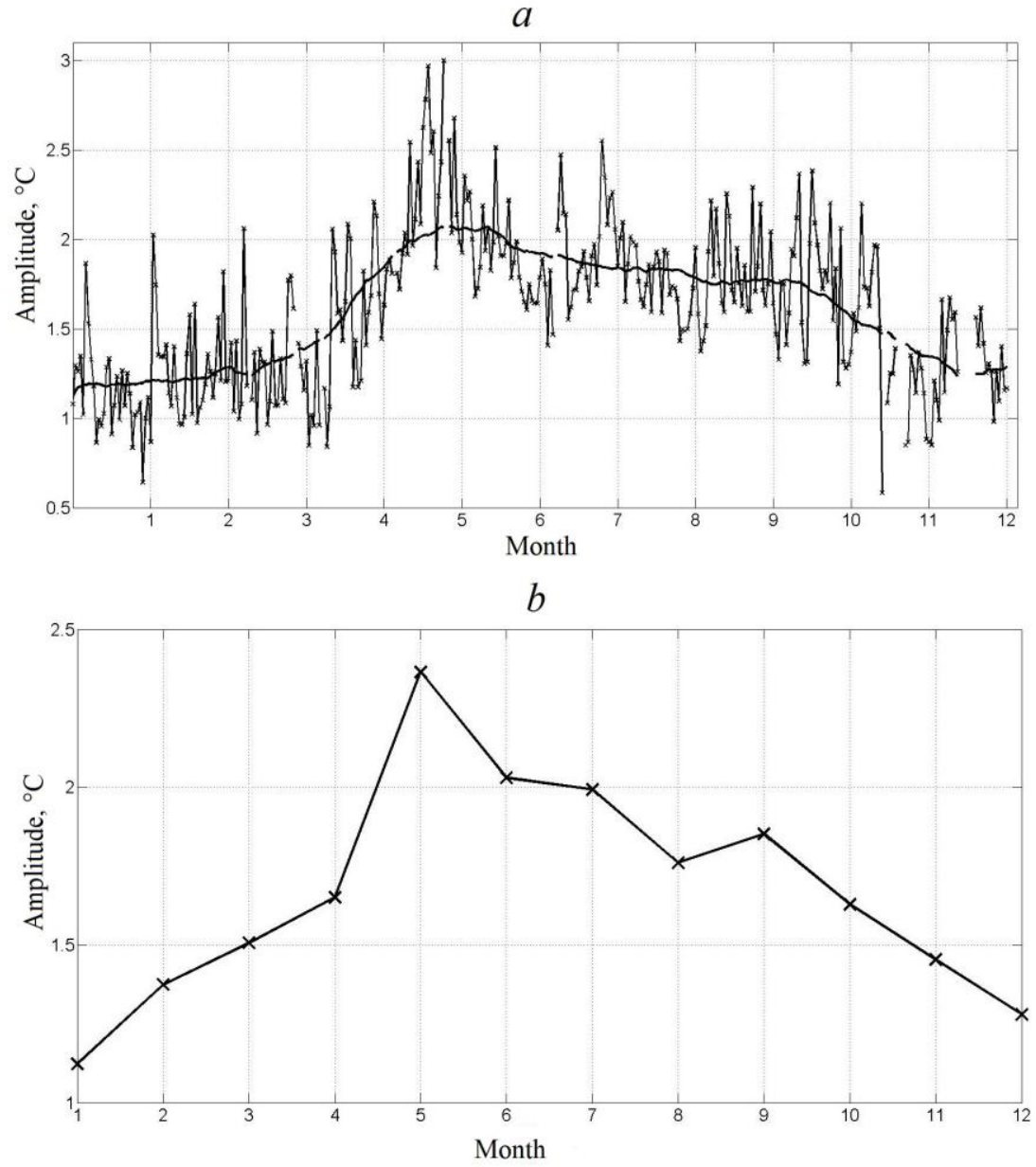

F i g. 6. Graph of variability of the SST diurnal cycle amplitude $A$ for 2015 smoothed by the moving average with a window length 30 days $(a)$, variations of the monthly average amplitude of the SST diurnal cycle for $2015(b)$

The map in Fig. 7, $a$ demonstrates the presence of spatial features in the amplitude distribution of the diurnal variation. The greatest diurnal difference in SST (i.e. warming) is observed in the southeast area and in the coastal part of the southwestern Black Sea. The lowest values of $A$ are characteristic of its central and western parts. Such spatial variability is associated primarily with the distribution of the wind speed field (Fig. 7,b), which, in turn, depends on the land relief surrounding the Black Sea. The elevated amplitudes of the diurnal variation are located in the zones of the wind shadow. In the coastal areas of the southeastern part of the sea, the high Caucasus mountains block the winds of the eastern and northeastern points, and the Pontine mountains in the south are blocked by southern winds. Thus, there is a vast area of wind shadow. The coastal southwestern part of the sea is also protected from the action of strong northeast winds by the Pontic Mountains on the central Anatolian coast. The western and 
northern parts of the sea are exposed to intense northeastern and northern winds, which leads to a decrease in SST diurnal cycle.
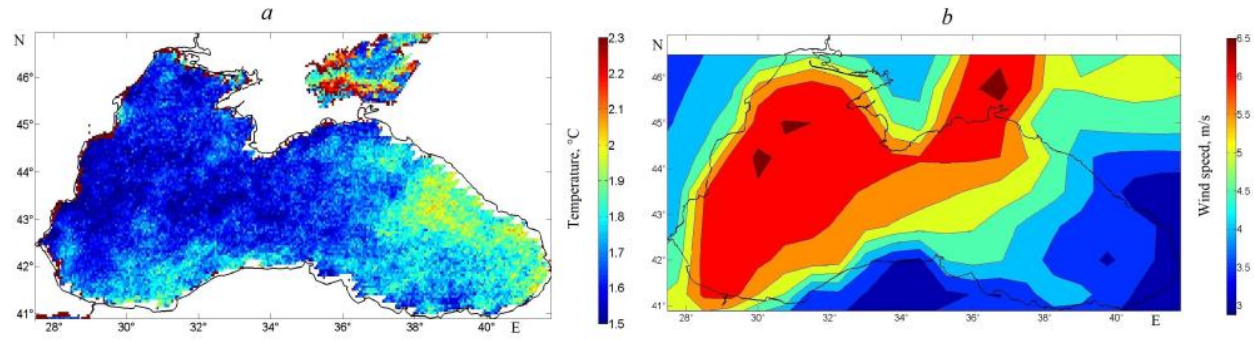

F i g. 7. Spatial distribution of: $a$ - annual average amplitude of the SST diurnal cycle $\left({ }^{\circ} \mathrm{C}\right) ; b-$ annual average wind speed module $(\mathrm{m} / \mathrm{s})$

\section{Conclusion}

In the present work, based on high-frequency measurements of the SEVIRI scanner with a 1-hour discreteness, the features of the spatial and seasonal variability of the SST diurnal cycle and its relationship with wind characteristics were studied. The following results were obtained.

1. The largest daily SST deviations from the average seasonal values are observed in the spring-summer period (from April to July), the smallest - in the autumn-winter period (November - March). The maximum absolute values of SST anomalies $\left(0.82{ }^{\circ} \mathrm{C}\right.$ in the direction of increasing temperature and $0.77{ }^{\circ} \mathrm{C}$ in the direction of decreasing) are noted in June. Minimal anomalies are observed from mid-November to March and do not exceed $0.1-0.2{ }^{\circ} \mathrm{C}$ in absolute value. During the day, the upper layer warming on average occurs from 6:00 to 17:00, and cooling from 19:00 to 5:00 the next morning.

2. A number of intensive diurnal warming events are considered. It was shown that in some events the amplitude of the SST diurnal variation exceeded $5{ }^{\circ} \mathrm{C}$ and reached extremely high values $-7-7.2^{\circ} \mathrm{C}$. Calm conditions in which the wind speed did not exceed $4 \mathrm{~m} / \mathrm{s}$ for a day or more over the main part of the Black Sea area contributed to the development of diurnal warming. The most frequent diurnal warming events were observed in May, when the wind speed was minimal.

3. The seasonal variability of the amplitude of the SST diurnal variation $A$ was studied. From January to April, its smooth increase is observed; in winter, the values of $A$ are minimal and do not exceed $1.5^{\circ} \mathrm{C}$. From April there is a sharp increase to the maximum value of $2.4{ }^{\circ} \mathrm{C}$ in May, after which it gradually decreases. In summer $A$ takes the values of $1.7-2{ }^{\circ} \mathrm{C}$. In autumn $A$ further decreases from $1.85{ }^{\circ} \mathrm{C}$ in September to $1.45{ }^{\circ} \mathrm{C}$ in November. The increased amplitudes of the diurnal variation are located in the zones of the wind shadow, which is formed by the Caucasian and Pontic Mountains. The western and northern parts of the sea are exposed to intense northeastern and northern winds, which leads to a decrease in the SST diurnal cycle.

The SST diurnal variation can significantly affect the heat (see, for example, [24]) and impulse fluxes and breeze circulation. Particularly, diurnal heating can significantly increase latent heat flows, on more than $10 \mathrm{~W} / \mathrm{m}^{2}$ [24]. The study of the SST diurnal cycle effect on the processes in the atmosphere in the Black Sea area is an important task that requires specific numerical experiments. 


\section{REFERENCES}

1. Meredith, E.P., Semenov, V.A., Maraun, D., Park, W. and Chernokulsky, A.V., 2015. Crucial Role of Black Sea Warming in Amplifying the 2012 Krymsk Precipitation Extreme. Nature Geoscience, [e-journal] 8(8), pp. 615-619. doi:10.1038/ngeo2483

2. Efimov, V.V. and Barabanov, V.S., 2009. Breeze Circulation in the Black-Sea Region. Physical Oceanography, [e-journal] 19(5), pp. 289-300. https://doi.org/10.1007/s11110-0109054-6

3. Efimov, V.V. and Krupin, A.V., 2016. Breeze Circulation in the Black Sea Region. Russian Meteorology and Hydrology, [e-journal] 41(4), pp. 240-246. https://doi.org/10.3103/S1068373916040026

4. Marullo, S., Minnett, P.J., Santoleri, R. and Tonani, M., 2016. The Diurnal Cycle of SeaSurface Temperature and Estimation of the Heat Budget of the Mediterranean Sea. Journal of Geophysical Research: Oceans, [e-journal] 121(11), pp. 8351-8367. https://doi.org/10.1002/2016JC012192

5. Grodsky, S.A., Kudryavtsev, V.N., Bentamy, A., Carton, J.A. and Chapron, B., 2012. Does Direct Impact of SST on Short Wind Waves Matter for Scatterometry? Geophysical Research Letters, [e-journal] 39(12), L12602. https://doi.org/10.1029/2012GL052091

6. Meissner, T., Wentz, F., Hilburn, K., Lagerloef, G. and Le Vine, D., 2012. The Aquarius Salinity Retrieval Algorithm. In: IEEE, 2012. 2012 IEEE International Geoscience and Remote Sensing Symposium: Proceedings. Munich, pp. 386-388. doi:10.1109/IGARSS.2012.6351557

7. Greenwald, T.J., Stephens, G.L., Vonder Haar, T.H. and Jackson, D.L., 1993. A Physical Retrieval of Cloud Liquid Water over the Global Oceans Using Special Sensor Microwave/Imager (SSM/I) Observations. Journal of Geophysical Research: Atmospheres, [e-journal] 98(D10), pp. 18471-18488. https://doi.org/10.1029/93JD00339

8. Castro, S.L., Wick, G.A. and Buck, J.J.H., 2014. Comparison of Diurnal Warming Estimates from Unpumped Argo Data and SEVIRI Satellite Observations. Remote Sensing of Environment, [e-journal] 140, pp. 789-799. https://doi.org/10.1016/j.rse.2013.08.042

9. Gentemann, C.L., Minnett, P.J., Le Borgne, P. and Merchant, C.J., 2008. Multi-Satellite Measurements of Large Diurnal Warming Events. Geophysical Research Letters, [e-journal] 35(22), L22602. https://doi.org/10.1029/2008GL035730

10. Marullo, S., Santoleri, R., Banzon, V., Evans, R.H. and Guarracino, M., 2010. A DiurnalCycle Resolving Sea Surface Temperature Product for the Tropical Atlantic. Journal of Geophysical Research: Oceans, [e-journal] 115(C5), C05011. https://doi.org/10.1029/2009JC005466

11. Merchant, C.J., Filipiak, M.J., Le Borgne, P., Roquet, H., Autret, E., Piollé, J.- F. and Lavender, S., 2008. Diurnal Warm-Layer Events in the Western Mediterranean and European Shelf Seas. Geophysical Research Letters, [e-journal] 35(4), L04601. https://doi.org/10.1029/2007GL033071

12. Filipiak, M.J., Merchant, C.J., Kettle, H. and Le Borgne, P., 2012. An Empirical Model for the Statistics of Sea Surface Diurnal Warming. Ocean Science, [e-journal] 8(2), pp. 197-209. https://doi.org/10.5194/os-8-197-2012

13. Karagali, I. and Høyer, J.L., 2014. Characterisation and Quantification of Regional Diurnal SST Cycles from SEVIRI. Ocean Science, [e-journal] 10(5), pp. 745-758. https://doi.org/10.5194/os-10-745-2014

14. Akimov, E.A., Stanichny, S.V. and Polonsky, A.B., 2014. Ispol'zovanie Dannykh Skanera SEVIRI Dlya Otsenki Temperatury Poverkhnostnogo Sloya Chernogo Morya [Application of SEVIRI Scanner Data for Temperature Estimation of the Surface Layer of the Black Sea]. Morskoy Gidrofizicheckiy Zhurnal, (6), pp. 37-46 (in Russian).

15. Saunders, P.M., 1967. The Temperature at the Ocean-Air Interface. Journal of the Atmospheric Sciences, [e-journal] 24(3), pp. 269-273. https://doi.org/10.1175/15200469(1967)024<0269:TTATOA>2.0.CO;2

16. Dee, D.P., Uppala, S.M., Simmons, A.J., Berrisford, P., Poli, P., Kobayashi, S., Andrae, U., Balmaseda, M.A. and Balsamo, G. [et al.], 2011. The ERA-Interim Reanalysis: Configuration 
and Performance of the Data Assimilation System. Quarterly Journal of the Royal Meteorological Society, [e-journal] 137(656), pp. 553-597. doi:10.1002/qj.828

17. Garmashov, A.V., Kubryakov, A.A., Shokurov, M.V., Stanichny, S.V., Toloknov, Yu.N., Korovushkin, A.I., 2016. Comparing Satellite and Meteorological Data on Wind Velocity over the Black Sea. Izvestiya, Atmospheric and Oceanic Physics, [e-journal] 52(3), pp. 309316. https://doi.org/10.1134/S000143381603004X

18. Efimov, V.V. and Anisimov, A.E., 2011. Climatic Parameters of Wind-Field Variability in the Black Sea Region: Numerical Reanalysis of Regional Atmospheric Circulation. Izvestiya, Atmospheric and Oceanic Physics, [e-journal] 47(3), pp. 350-361. https://doi.org/10.1134/S0001433811030030

19. Il'in, Yu.P., Repetin, L.N., Belokopytov, V.N., Goryachkin, Yu.N., D'yakov, N.N., Kubryakov, A.A. and Stanichny, S.V., 2012. Gidrometeorologicheskie Usloviya Morey Ukrainy. T. 2. Chernoye More [Hydrometeorological Conditions of the Seas of Ukraine. Vol. 2. Black Sea]. Sevastopol: 421 p. (in Russian).

20. Zatsepin, A.G., Kremenetskiy, V.V., Piotukh, V.B., Poyarkov, S.G., Ratner, Yu.B., Soloviev, D.M., Stanichnaya, R.R., Stanichny, S.V. and Yakubenko, V.G., 2008. Formation of the Coastal Current in the Black Sea Caused by Spatially Inhomogeneous Wind Forcing upon the Upper Quasi-Homogeneous Layer. Oceanology, [e-journal] 48(2), pp. 159-174. https://doi.org/10.1134/S0001437008020021

21. Efimov, V.V. and Barabanov, V.S., 2017. Anomalies of the Black Sea Surface Temperature and Modeling of Intense Cold Anomaly Formation in September 2014. Izvestiya, Atmospheric and Oceanic Physics, [e-journal] 53(3), pp. 343-351. https://doi.org/10.1134/S0001433817030057

22. Efimov, V.V. and Komarovskaya, O.I., 2017. Formirovanie Krupnomasshtabnoj Holodnoj Anomalii Poverhnostnoj Temperatury Chernogo Morja po Sputnikovym Dannym [Formation of the Cold Long-Lasting Anomaly of Black Sea Surface Temperature According to Satellite Data]. Current Problems in Remote Sensing of the Earth from Space, 14(7), pp. 238-249. doi:10.21046/2070-7401-2017-14-7-238-249 (in Russian).

23. Efimov, V.V., Stanichnyi, S.V., Shokurov, M.V., Yarovaya, D.A., 2008. Observations of a Quasi-Tropical Cyclone over the Black Sea. Russian Meteorology and Hydrology, [ejournal] 33(4), pp. 233-239. https://doi.org/10.3103/S1068373908040067

24. Clayson, C.A. and Bogdanoff, A.S., 2013. The Effect of Surface Temperature Warming on Climatological Air-Sea Fluxes. Journal of Climate, [e-journal] 26(8), pp. 2546-2556. https://doi.org/10.1175/JCLI-D-12-00062.1

About the authors:

Valentina A. Rubakina - Junior Research Associate, Marine Hydrophysical Institute of RAS (2 Kapitanskaya St., Sevastopol, Russian Federation, 299011), Ph.D. (Phys.-Math), ORCID ID: 0000-0003-3561-5913, valenru93@mail.ru

Arseniy A. Kubryakov - Senior Research Associate, Marine Hydrophysical Institute of RAS (2 Kapitanskaya St., Sevastopol, Russian Federation, 299011), Ph.D. (Phys.-Math), ORCID ID: 0000-0003-3561-5913, arskubr@mhi-ras.ru

Sergey V. Stanichny - Senior Research Associate, Head of Remote Sensing Department, Marine Hydrophysical Institute of RAS (2 Kapitanskaya St., Sevastopol, Russian Federation, 299011), Ph.D. (Phys.-Math), ORCID ID: 0000-0002-1033-5678, stanichny@ mhi-ras.ru

All the authors have read and approved the final manuscript.

The authors declare that they have no conflict of interest. 